Tropical Journal of Pharmaceutical Research, December 2009; 8 (6): 551-555

(C) Pharmacotherapy Group,

Faculty of Pharmacy, University of Benin

Benin City, 300001 Nigeria.

All rights reserved.

Research Article

Available online at http://www.tjpr.org

\title{
Antioxidant Properties of Diospyros Preussi (Ebenaceae Gurke) Seed Oil
}

\author{
Tochukwu JN Okonkwo ${ }^{1 *}$ and Chinedu JO Okonkwo ${ }^{2}$ \\ ${ }^{1}$ Department of Pharmaceutical Chemistry, Faculty of Pharmaceutical Sciences, University of Port Harcourt, Choba, \\ Rivers State, Nigeria \\ ${ }^{2}$ Division of Biochemistry, Department of Chemical Sciences, Faculty of Natural Sciences, Novena University, \\ Ogume, Delta State, Nigeria.
}

\begin{abstract}
Purpose: To evaluate the lipid peroxidation inhibiting and glutathione-sparing activities (i.e., antioxidant effect) of Diospyros preussi seed oil in male Wistar albino rats.

Methods: The n-hexane extract of the seed (seed oil) of Diospyros preussi (DP) was tested for its antioxidant properties against hydrogen peroxide $\left(\mathrm{H}_{2} \mathrm{O}_{2}\right)$-induced oxidative stress in male Wistar albino rats by evaluating its lipid peroxidation inhibition and glutathione-sparing activity (free radical scavenging effect). Vitamin $E$, at a dose of $4 \mathrm{ml} / \mathrm{kg}$ body weight, was used reference. These parameters were determined in vivo by assaying the levels of thiobarbituric acid reactive substance (TBARS) and reduced glutathione (GSH) in the serum of exposed and normal Wistar albino rats.

Results: At doses of 500 and $1000 \mathrm{mg} / \mathrm{kg}$ of DP seed oil, the values of thiobarbituric acid-reactive substances, TBARS, $(0.80 \pm 0.04$ and $0.72 \pm 0.01 \mu \mathrm{g} / \mathrm{ml}$, respectively) were not significantly different ( $p$ $<0.05)$ from the TBARS level of $0.83 \pm 0.03 \mu \mathrm{g} / \mathrm{ml}$ induced by the reference, Vitamin E. Animals treated with 1000,500 and $200 \mathrm{mg} / \mathrm{kg}$ doses of DP seed oil manifested glutathione levels of $206.7 \pm 6.5,188.0$ \pm 4.7 and $156.0 \pm 7.6 \mu \mathrm{g} / 100 \mathrm{ml}$ of serum, respectively. These levels were significantly different from each other at $p<0.05$ as well as the level $(138.7 \pm 8.0 / 100 \mathrm{ml})$ produced by the reference, Vitamin $E$.

Conclusion: The results indicate that DP seed oil significantly protected the rats from $\mathrm{H}_{2} \mathrm{O}_{2}$-induced oxidative stress. Furthermore, its antioxidant effect is dose-related.
\end{abstract}

Keywords: Seed oil; Diospyros preussi; $\left(\mathrm{H}_{2} \mathrm{O}_{2}\right)$-induced oxidative stress; Antioxidant effect, Vitamin E; Lipid peroxidation inhibition; Glutathione-sparing activity 


\section{INTRODUCTION}

Trees and shrubs with medicinal and nutritional potentials abound in the tropics [1]. Several of these plants produce fruits which have been identified to be nutritionally important [2]. One of such, Diospyros preussi (Ebenaceae Gurke), which comprises 450 500 species, is widely distributed across the tropics, with the greatest diversity of species in Indomalaya [3]. Members are mostly evergreen and native to the tropics and subtropics, with a few deciduous species native to temperate regions [3]. Diospyros preussi is a tree with small solitary white flowers shaped like lanterns or bells, and fruits once a year $[4,5]$. Its fruits are eaten by woodland animals and humans; and the seeds are usually thrown away. The heartwood may cause dermatitis [6] while its seed is large, endospermic and oily [4]. $D$. preussi is economically important for its timber and fruits.

Reactive oxygen species (ROS), such as superoxide anion, hydrogen peroxide, hydroxyl radical, nitric oxide, and peroxynitrite radical play an important role in oxidative stress related to the pathogenesis of various diseases $[7,8]$. In healthy individuals, endogenously produced free radicals are neutralised by a battery of antioxidants. Thus, oxidative stress is generated when equilibrium favours free radicals generation as a result of a depletion of antioxidant levels. The oxidation of lipids, DNA, proteins, carbohydrates, and other molecules, and glutathione depletion by toxic ROS may cause DNA mutation and/or severe damage to target cells or tissues, and this often results in cell senescence and death [9].

Antioxidant agents of natural origin have attracted special interest because they can protect the human body from free radicals [10]. Moreover, knowledge and application of such potential antioxidant activities in reducing oxidative stress in vivo has prompted many investigators to search for potent and cost-effective antioxidants from various plant sources $[9,11,12]$. These research studies have contributed to new and renewed public interests worldwide in herbal medicines, health foods and nutritional supplements [9]. The present study was aimed at evaluating the lipid peroxidation inhibition and glutathione-sparing activities of $D$. preussi seed oil in male Wistar albino rats subjected to $\mathrm{H}_{2} \mathrm{O}_{2}$-induced oxidative stress.

\section{EXPERIMENTAL}

\section{D. preussi seeds}

The seeds were collected from Nsukka, Enugu State, Nigeria, and were authenticated by $\mathrm{Mr}$ JA Ekekwe of the Department of Botany, University of Nigeria, Nsukka. A voucher specimen, no. $\mathrm{UNH} / 204$, was deposited at the department's herbarium. The seeds were air-dried at ambient temperature and pulverised to a coarse powder. The seed oil was subsequently extracted in a soxhlet apparatus at $65-70{ }^{\circ} \mathrm{C}$ with $\mathrm{n}$-hexane as solvent for $8 \mathrm{~h}$. The extract was dried in vacuo at less than $40{ }^{\circ} \mathrm{C}$ in a rotating evaporator to obtain golden yellow oil. Percent oil yield was estimated gravimetrically.

\section{Animals}

Male Wistar albino rats $(83-120 \mathrm{~g} ; 8-12$ weeks old) were used for the investigation. The rats were obtained from the Faculty of Veterinary Medicine of the same university, and were fed Top Feeds starter/chick mash obtained commercially. The animals were handled in accordance with the guidelines of the University of Nigeria Ethical Committee on the use of experimental animals and humans in bioresearch [13]. The animal study was approved by the ethics committee.

\section{$\mathrm{H}_{2} \mathrm{O}_{2}$-induced oxidative stress}

Eighteen rats were housed in cages and divided into six groups of three each. Group I (normal control) was given Tween 80 in a single daily dose of $5.0 \mathrm{ml} / \mathrm{kg}$ body weight per 
oral (p.o.) for 4 days and single hydrogen peroxide $\left(\mathrm{H}_{2} \mathrm{O}_{2}, 20 \% \mathrm{v} / \mathrm{v}\right)$ doses of 0.5 and $1.0 \mathrm{ml} / \mathrm{kg}$ intraperitoneally (i.p.) as well on the third and fourth day, respectively. Group II $\left(\mathrm{H}_{2} \mathrm{O}_{2}\right.$ control) received a single daily dose of $0.5 \mathrm{ml} \mathrm{H} \mathrm{H}_{2} / \mathrm{kg}$ i.p. for 3 days and a single dose of $1.0 \mathrm{ml} \mathrm{H} \mathrm{O}_{2} / \mathrm{kg}$ i.p. on day 4. Group III (vitamin $\mathrm{E}$ control) received a daily dose of $4.08 \mathrm{ml} / \mathrm{g}$ of vitamin E (1000 IU, d-alphatocopheryl acetate soft-gel capsule) p.o. for 4 days, and single doses of 0.5 and $1.0 \mathrm{ml} / \mathrm{kg}$ of $\mathrm{H}_{2} \mathrm{O}_{2}$ i.p. on days 3 and 4, respectively. Groups IV, V and VI (test groups) received a single daily dose of DP seed oil p.o. for 4 days (200, 500 and $1000 \mathrm{mg} / \mathrm{kg}$, respectively), and a single dose of 0.5 and $1.0 \mathrm{ml} / \mathrm{kg}$ of $\mathrm{H}_{2} \mathrm{O}_{2}$ i.p. as well on days 3 and 4 , respectively. After treatment for 4 days, the animals were fasted for $24 \mathrm{~h}$ but had free access to water. They were sacrificed on the fifth day and blood collected via ocular puncture. The blood samples were centrifuged and sera collected for lipid peroxidation and glutathione assay. The procedure used in this investigation is a modification of the method of Suja et al [12]

\section{Lipid peroxidation assay}

Lipid peroxidation in the supernatant fractions was determined spectrophotometrically by assessing the levels of thiobarbituric acid reactive substances (TBARS), and malondialdehyde (MDA), following the method of Northwest Life Science Specialties (NWLSS) [14]. Serum (0.4 ml) was mixed with $1.6 \mathrm{ml}$ of $0.5 \mathrm{mM}$ Tris $\mathrm{KCl}$ buffer followed by the addition of $0.5 \mathrm{ml}$ of $2 \%$ trichloroacetic acid (TCA). $0.5 \mathrm{ml}$ of $52 \mathrm{mM}$ thiobarbituric acid (TBA) was then added and the mixture placed in a water bath for $45 \mathrm{~min}$ at $80{ }^{\circ} \mathrm{C}$. At the expiration of the incubation period, the mixture was allowed to cool and centrifuged at $3000 \mathrm{rpm}$ for $10 \mathrm{~min}$. The absorbance of the clear supernatant was measured against a reference blank of distilled water at $532 \mathrm{~nm}$. The concentration of TBARS was then derived from the standard curve of lipid peroxidation.

\section{Glutathione assay}

Serum glutathione levels were determined by the method of NWLSS ${ }^{\mathrm{TM}}$ Glutathione Assay [15]. Serum $(0.1 \mathrm{ml})$ of each sample was taken in a test tube and made up to $1 \mathrm{ml}$ with distilled water. To this, $0.02 \mathrm{ml}$ of $20 \%$ sodium sulphate solution was added and properly shaken. Two minutes later, $0.02 \mathrm{ml}$ of $20 \%$ lithium sulphate and $0.2 \mathrm{ml}$ of $20 \%$ sodium carbonate were added, and shaken properly. This was followed by the addition of $0.2 \mathrm{ml}$ phosphorus 18 tungsten acid reagent. Again, the tube was shaken and allowed to stand for 4 min to develop maximum colour. It was then made up to $2.5 \mathrm{ml}$ with $2 \%$ sodium sulphate solution to prevent re-oxidation, and absorbance read against a blank at $610 \mathrm{~nm}$ within $10 \mathrm{~min}$ to avoid bleaching. The glutathione concentration was then derived from the standard curve for glutathione.

\section{Statistical analysis}

The results were expressed as mean \pm SEM. Means were compared for statistically significant difference using one-way analysis of variance (ANOVA). Effects were considered significant at $p<0.05$ in all cases.

\section{RESULTS}

An oil yield of $34.9 \%$, on a dry basis, indicated that $D P$ seed is a rich source of neutral lipid. The results for lipid peroxidation are shown in Table 1. The vehicle, Tween 80 , had no antioxidant activity as the extent of lipid peroxidation in the normal control was close to that of the $\mathrm{H}_{2} \mathrm{O}_{2}$ control. DP seed oil showed a dose-dependent lipid peroxidation inhibiting property. At $D P$ seed oil doses of 500 and $1000 \mathrm{mg} / \mathrm{kg}$, the levels of TBARS were lower than that of the vitamin $\mathrm{E}$ group (1000 IU). However, the lipid peroxide inhibition expressed by both the oil and vitamin $E$, in relation to the normal control, was significant at $p<0.05$.

Table 1 also shows the glutathione-sparing activity of the various animal groups. At the 
Table 1: Serum levels of thiobarbituric acid reactive substances (TBARS) and glutathione

\begin{tabular}{lcc}
\hline Treatment group & TBARS $(\mu \mathrm{g} / \mathrm{ml})$ & Glutathione level $(\mu \mathrm{g} / 100 \mathrm{ml})$ \\
\hline Group I (Normal control) & $1.26 \pm 0.09$ & $33.33 \pm 5.96$ \\
Group II (Negative control) & $1.40 \pm 0.12$ & $10.67 \pm 6.24$ \\
Group III (Positive control) & $0.83 \pm 0.03$ & $138.67 \pm 8.00$ \\
Group IV (200 mg/kg) & $0.86 \pm 0.02^{*}$ & $156.00 \pm 7.62^{+}$ \\
Group V (500 mg/kg) & $0.80 \pm 0.04^{*}$ & $188.00 \pm 4.72^{*}$ \\
Group VI (1000 mg/kg) & $0.72 \pm 0.01^{*}$ & $206.67 \pm 6.47^{*}$ \\
\hline
\end{tabular}

\#4.08 ml/kg vit. E (1000 IU, d-alpha-tocopheryl acetate soft-gel capsule).

${ }^{*} p<0.05$, with respect to the positive control.

${ }^{+} p<0.05$, with respect to the positive control.

dose used, vitamin $\mathrm{E}$ maintained serum glutathione level at $138.7 \pm 8.0 \mu \mathrm{g} / 100 \mathrm{ml}$ while the glutathione level in unprotected animals (Group II) was $10.7 \pm 6.2 \mu \mathrm{g} / 100 \mathrm{ml}$. In the normal control, the value was $33.3 \pm$ $6.0 \mu \mathrm{g} / 100 \mathrm{ml}$. The glutathione levels of animals treated with DP seed oil doses of 200,500 and $1000 \mathrm{mg} / \mathrm{kg}$ were $206.7 \pm 6.5$, $188.0 \pm 4.7$ and $156.00 \pm 7.62 \mu \mathrm{g} / 100 \mathrm{ml}$, respectively. The results were dose-related and significantly $(p<0.05)$ higher than that of the corresponding value for vitamin $\mathrm{E}$

\section{DISCUSSION}

Free radicals are believed to be involved in bacterial and parasitic infections, lung damage, inflammation, reperfusion injury, cardiovascular disorders, atherosclerosis, ageing and neoplastic diseases [16]. These free radicals, also known as reactive oxygen species (ROS), include oxygen and nonoxygen radicals. Among the oxygen radicals are singlet oxygen, superoxide anion, hydrogen peroxide and hydroxyl radicals. In biochemical systems, $\mathrm{H}_{2} \mathrm{O}_{2}$ generates extremely reactive hydroxyl radicals in the presence of certain transition metal ions (e.g. iron and copper) or by ultraviolet (UV) photolysis [9]. Hydroxyl radicals can attack DNA molecules, cause lipid peroxidation [17], tissue damage, protein denaturation and glutathione depletion [18].

Glutathione, a tripeptide with a thiol group, is found in plants and animals in both its reduced and dimeric forms. In the reduced (monomeric) form, glutathione is a powerful endogenous antioxidant, protecting biological systems from degenerative damages associated with ageing and oxidative stress [18]. Glutathione participates in leukotriene synthesis and is a co-factor for the enzyme, glutathione peroxidase - an enzyme that scavenges $\mathrm{H}_{2} \mathrm{O}_{2}$ and other peroxides. This selenium-containing enzyme, requiring glutathione co-factor, is a major antioxidant enzyme. Hence, oxidative imbalance will result in depletion of glutathione, due to increased activity of glutathione peroxidase, in the face of oxidative stress generated by $\mathrm{H}_{2} \mathrm{O}_{2}$ and other peroxyl radicals.

Excessive lipid peroxidation among Group I and II animals, confirmed the ability of $\mathrm{H}_{2} \mathrm{O}_{2}$, at the dose used, to induce oxidative stress in animals. $D P$ seed oil significantly inhibited lipid peroxidation and glutathione depletion arising from $\mathrm{H}_{2} \mathrm{O}_{2}$-induced oxidative stress. Since lipid peroxidation and glutathione are generated as a result of oxidative imbalance and this imbalance was counteracted by $D P$ seed oil, the oil can be said to be an effective antioxidant. Its antioxidant activity is probably mediated through chain breaking which leads to reduction of free radicals. Vitamin $E$ shares a similar mechanism [19]. It is known that vitamin $E$ and carotenoids (especially $\beta$ carotene) are usually components of lipids $[20,21]$. The antioxidant activities of these phytochemicals are well established [19,21], and have been demonstrated to exert their effects via chain breaking $[19,22]$. Although total lipid analysis of DP seed oil is on-going, 
$D P$ seed oil contains these compounds in large amounts.

\section{CONCLUSION}

Our findings demonstrate the intrinsic ability of $D P$ seed oil to counteract oxidative imbalance in rats. However, further studies are required before it can be recommended for use as a nutritional supplement, health food and adjuvant in the management of patho-oxidative disorders.

\section{ACKNOWLEDGEMENTS}

The authors thank Mr. OGB Ikweagwu, Department of Biochemistry, University of Nigeria, Nsukka, Nigeria for technical assistance and facilities; and Mr. JA. Ekekwe, Department of Botany of same university, for authentication of the plant material.

\section{REFERENCES}

1. Burkill HM. A review of Delziel's the useful plants of West Africa, vol. 1, Royal Botanical Garden Kew, UK; 1985. p 2.

2. Ihekoronye Al, Ngoddy PO. Integrated Food Science and Technology for the tropics. Macmillian Publishers Ltd, UK; 1985. pp 8293.

3. Wikipedia (The Free Encyclopedia), Diospyros sp. (Last modified 09:19, 24 February, 2007; [cited 20 July, 2009]. http://nl.wikipedia.org/wiki/ Diospyros.

4. Wastson L, Dallwitz MJ. The families of flowering plants: descriptions, illustrations, identification and information retrieval. (Version: 9th September, 2009); [cited 2009 October, 8]. http://delta-intkey.com/angio/www/ebenaceae .htm

5. Little EL. Checklist of United States Trees (Native and Naturalised). Agric. Handbook. U. S. Government Printing Office; 1979; $p 541$.

6. Woods B, Calhan CD. Toxic Woods. British Journal of Dermatology 1976; 1056.

7. Halliwell B, Gutteridge JMC. Free radicals in Biology and Medicine. 3rd edition.Oxford University Press, Oxford, UK, 1999.

8. Finkel $T$, Holbrook NJ. Oxidants, oxidative stress and the biology of aging. Nature 2000; 408: 239-247.
9. Shyur L-F, Tsung J-H, Chen J-H, Chiu C-Y, Lo C-P. Antioxidant properties of extracts from medicinal plants popularly used in Taiwan. Int. J. App. Sci. and Engr. 2005; 3(3): 195 - 202.

10. Osawa T, Kavakishi S, Namiki M. In: Kuroda $Y$, Shankai DM, Waters MD. Antimutagenesis and anticarcinogenesis mechanisms II. New York: Plenum; 1990; $p 139$.

11. Baheti JR, Kumar V, Shah GB, Goyal RK. Free radical scavenging activity of aqueous extract of Rhus succederea galls. J. Natural Remedies 2005; 5(1): 15-18.

12. Suja SR, Latha PG, Pushpangadan $P$, Rajasekharan $S$. Assessment of hepatoprotective and free radical scavenging effects of Rhinacanthus nasuta (Linn.) Kurz in wistar rats. J. Nat. Rem. 2004; 4(1): 66-72.

13. Uni. of Nig. Bio-research Ethical Committee (UNBEC). University of Nigeria Ethical Guidelines on the use of laboratory animals and humans in boi-research. University of Nigeria Press Ltd, Nsukka; 2006. pp. 1-30.

14. NWLSS ${ }^{T M}$ Lipid Peroxidation Assay (NWLSS ${ }^{T M}$ NWK - MDA01). Northwest Life Science Specialties, LLC.5131 NE 94th Avenue, Suite 201, Vancouver, WA 98662, Canada. http://www.nwlifescience.com/products/pdf/nw kmda01\% 20rev111507.pdf. Accessed 2009 August, 20.

15. NWLSS ${ }^{M M}$ Glutathione Assay (NWLSS ${ }^{T M}$ NWK GSH01). Northwest Life Science specialties, LLC. 5131 NE 94th Avenue, Suite 201; Vancourver WA 98662, Canada. http://www.jaica.com/pdf/gsh_kit_instruction. pdf. Accessed 2009 August, 20.

16. Burdon $R H$. Free radical damage and its control. Elsevier Science B. V. Netherland; 1994. p. 125.

17. Getteridge JM, Halliwell B. Lipid peroxidation and antioxidants as biomarkers of tissue damage. Clin. Chem. 1995; 41: 1819-1828.

18. Nelson DL, Michael UC. "Role of mitochondria in oxidative stress". Lehninger Principles of Biochemistry 4th edition. W. H. Freeman Company; 2003. pp. 721-722.

19. Di Mascio P, Murphy ME, Sies H. Antioxidant defence systems: the role of carotenoids and tocopherols. Am. J. Clin. Nutri. 1991; 53: 1945-2005.

20. Gunstone FD. Fatty acid and lipid Chemistry. Aspen Publishers Inc. Gaithersburg, Maryland 20878; 1999. pp. $6,10,15$.

21. Harbone JB. Phytochemical Methods, III ed. Chapman and Hall; 1998. pp. 159-170.

22. Mortensen A, Skibsted LH, Sampson J, Rice-Evans $C$, Everett $S A$. Comparative mechanism and free radical scavenging by carotenoid antioxidants. FEBS Letters 1997; 418: 91-97. 